\title{
Influence of postoperative enteral nutrition on postsurgical infections
}

\author{
R Beier-Holgersen, S Boesby
}

\begin{abstract}
Background-This study was undertaken to test the hypothesis that early enteral nutrition might reduce the incidence of serious complications after major abdominal surgery.

Methods-In a randomised double blind prospective trial 30 patients received Nutridrink and 30 patients received placebo through a nasoduodenal feeding tube. On the day of operation the patients were given median $600 \mathrm{ml}$ of either nutrition or placebo, $60 \mathrm{ml}$ per hour. On the first postoperative day the patients received either $1000 \mathrm{ml}$ (median) of nutrition or placebo, on day $21200 \mathrm{ml}$ (median) nutrition, $1400 \mathrm{ml}$ placebo, on day $31000 \mathrm{ml}$ (median) nutrition, $1150 \mathrm{ml}$ placebo, and on day $41000 \mathrm{ml}$ (median) nutrition, $800 \mathrm{ml}$ placebo. All patients were followed up for $\mathbf{3 0}$ days by the same investigator.

Results-The two groups were similar with regard to nutritional status and type of operation. The rate of postoperative infectious complications was significantly lower in the nutrition group, two of $\mathbf{3 0}$ compared with 14 of 30 in the placebo group $(p=0 \cdot 0009)$.

Conclusion-Early enteral nutrition given to patients after major abdominal surgery results in an important reduction in infectious complications.
\end{abstract}

(Gut 1996; 39: 833-835)

Departm

Gastroenterology D, Glostrup,

DK-2600 Glostrup,

Denmark

R Beier-Holgersen

$S$ Boesby

Correspondence to: Dr R Beier-Holgersen, Department of Surgical Gastroenterology D,

KAS-Glostrup,

Ndr Ringvej,

DK-2600 Glostrup,

Denmark.

Accepted for publication 8 July 1996
Keywords: enteral nutrition, infection, abdominal surgery.

In 1979 elemental feeding was given successfully by a double lumen tube from the first postoperative day to patients undergoing abdominal surgery. It was found that the patients had a better metabolical recovery and required a shorter stay in hospital. ${ }^{1}$ In 1983 Moore and Jones found that early nutritional support to trauma patients reduced the

TABLE I Characteristics of the operations

\begin{tabular}{lcc}
\hline Type of operation & $\begin{array}{c}\text { Group I } \\
\text { (Feeding) }\end{array}$ & $\begin{array}{c}\text { Group II } \\
\text { (Placebo) }\end{array}$ \\
\hline Oesophagogastrectomy & 2 & 1 \\
Gastrectomy & 2 & 3 \\
Colonic resection & 18 & 17 \\
Anterior resection & 2 & 5 \\
Abdominoperineal resection & 6 & 4 \\
Total number & 30 & 30 \\
Peroperative blood transfusions (no of patients) & 12 & 10 \\
Median operation time, minutes & 170 & 165 \\
Range, minutes & $(60-365)$ & $(60-365)$ \\
\hline
\end{tabular}

incidence of septic complications. Elemental diet infusion began 12 to 18 hours postoperatively. ${ }^{2}$ In a meta-analysis of the effect of enteral versus parenteral nutrition in high risk surgical patients the authors found that patients receiving enteral nutrition had a lower incidence of septic complications. ${ }^{3}$ None of these investigations were placebo controlled and therefore not blinded. In 1994 Consensus in Clinical Nutrition ${ }^{4}$ still concluded that, after major surgery, in a well nourished patient, nutritional support should only be considered if it was expected that it would be seven to 10 days or more before the patient could eat. A severely malnourished patient should receive nutritional support even if it is expected that the patient could eat before seven days. Enteral nutrition is not at the present time routine treatment in the early postoperative period after abdominal surgery.

We have investigated the effect of early postoperative enteral nutrition (Nutridrink) versus no nutrition (placebo) on the postoperative course in patients after major abdominal surgery. The study was designed as a randomised double blind prospective trial.

\section{Methods}

\section{Patients}

Sixty patients were randomly allocated to two comparable groups of 30 patients each. In group I (nutrition group) the ratio male/female was $18 / 12$, median age: 66.5 years, range 27-93. In group II (placebo group) the ratio male/female was $20 / 10$, median age: 61.5 years, range $27-80$. The height/weight values in group I were median $169.5 \mathrm{~cm} / 71.2 \mathrm{~kg}$, in group II: $172 \mathrm{~cm} / 68.5 \mathrm{~kg}$. In group I the ratio between malignant/benign disease was 19/11, in group II the ratio was $20 / 10$. Serum albumin concentrations were median $0.64 \mathrm{mmol} / \mathrm{l}$ (range $0.47-0.74 \mathrm{mmol} / \mathrm{l}$ ) in group $I$ and median $0.63 \mathrm{mmol} / 1$ (range $0.48-0.73 \mathrm{mmol} / \mathrm{l}$ ) in group II (NS), $C$ reactive protein concentration in group I was median $6.0 \mathrm{mg} / \mathrm{l}$ (range $<5-76 \mathrm{mg} / \mathrm{l}$ ), in group II $6.5 \mathrm{mg} / \mathrm{l}$ (range $<5-41 \mathrm{mg} / \mathrm{l})$ (NS). Table I lists the operations that were undertaken.

All patients who suffered from gastrointestinal diseases and who were treated by bowel resection with an anastomosis, an enterostomy, a gastric or oesophageal resection were considered for participation in this study irrespective of nutritional status. Patients with insulin dependent diabetes mellitus, inadequate renal or hepatic functions or inflammatory bowel disease were excluded. 
All patients were operated on at the same centre (Department of Surgical Gastroenterology, KAS Glostrup, Denmark). All received prophylactic antibiotics (penicillin, metronidazol, and gentamycin) depending of the type of surgery.

Before randomisation, well nourished and malnourished patients were stratified preoperatively by the following criteria: weight loss $>5 \%$ of normal body weight during the past three months before the operation. Malnourished patients were randomised separately. Of the nine malnourished patients four were allocated to group I and five to group II.

All patients were informed verbally and in writing and gave their consent before the operation.

Randomisation was carried out when the abdomen had been opened and the surgeon had decided that surgery was possible.

All patients had an epidural catheter with a pump to be used during operation and for postoperative pain relief (epimorphin $0.2 \mathrm{mg} / \mathrm{h}$ combined with bupivacain, $10 \mathrm{mg} / \mathrm{h}$ for at least 48 hours after the operation).

A nasoduodenal feeding tube (Flocare $125 \mathrm{~cm}, \mathrm{Ch} 10$ ) was positioned by the surgeon in the second to third part of the duodenum towards the end of the operation. This tube was used until the patient was able to drink sufficiently. A conventional nasogastric tube for aspiration was not used as routine.

The patients in group I received a nutrition supplement of Nutridrink (orange flavour), Nutricia, the Netherlands within four hours postoperatively. Nutridrink contains $150 \mathrm{kcal} /$ $100 \mathrm{ml}$ and $5 \mathrm{~g}$ protein $100 \mathrm{ml}$. The nutritional supplement was given until the fourth day. Patients in group II received placebo (water with orange flavour, no energy, vitamins or trace elements) during the same period. All patients were permitted to eat a normal diet from the fifth postoperative day if possible.

On the day of operation the patients were expected to take $600 \mathrm{ml}, 60 \mathrm{ml} / \mathrm{h}$. On the first postoperative day the patients were scheduled to receive $1000 \mathrm{ml}$, on day $21400 \mathrm{ml}$, and on days 3 and $41800 \mathrm{ml}$ if they could tolerate the formula. Additional tea, coffee, and water was permitted. Intravenous isotonic saline and glucose was given until the patient could drink sufficiently. The amounts of fluid taken were recorded. The principal investigator saw the patients every day during their stay in the ward, and all complications were recorded by the same investigator. Complications were classified according to Buzby's classification. ${ }^{5}$

Nutridrink or placebo in identical containers was administered by the nursing staff.

TABLE II Median amount of Nutridrink and placebo received daily

\begin{tabular}{llllll}
\hline & $\begin{array}{l}\text { Day of } \\
\text { operation } \\
(\mathrm{ml})\end{array}$ & $\begin{array}{l}\text { First } \\
\text { postoperative } \\
\text { day } \\
(\mathrm{ml})\end{array}$ & $\begin{array}{l}\text { Second } \\
\text { postoperative } \\
\text { day } \\
(\mathrm{ml})\end{array}$ & $\begin{array}{l}\text { Third } \\
\text { postoperative } \\
\text { dayt } \\
(\mathrm{ml})\end{array}$ & $\begin{array}{l}\text { Fourth } \\
\text { postoperative } \\
\text { dayt } \\
(\mathrm{ml})\end{array}$ \\
\hline $\begin{array}{l}\text { Group I/ } \\
\text { patients }\end{array}$ & 600 & 1000 & 1200 & 1000 & 1000 \\
Group IV & 30 & 30 & 29 & 25 & 21 \\
patients & 30 & 1000 & 1400 & 1150 & 800 \\
& 30 & 30 & 28 & 27 & 27 \\
\hline
\end{tabular}

^The number of patients who only received nutrition/placebo. †The tube had been removed. The patients were required to drink the product.
The randomisation code was not broken until all results were available and all patients had been followed up for 30 days after surgery and all complications classified. If a patient had more than one complication, only the first complication was noted for this study.

The cost per patient was estimated as follows. Each day the patient stayed in the surgical department the price was $3 \cdot 142 \mathrm{DKK}$ day, the price in the intensive care unit was 16.473 DKK/day, and every operation had an average cost of $11.247 \mathrm{DKK}$. In group I the expenses for tubes and nutrition were included.

\section{Statistics}

Fisher's exact test and the Mann-Whitney test were used. A p value of less than $5 \%$ was accepted as significant.

\section{Ethics}

The study was approved by the ethics committee of the Copenhagen County. The Helsinki Declaration II was followed.

\section{Results}

The patients in group I received a drink of $4000 \mathrm{ml}$ (median) Nutridrink (95\% confidence limits of the median: 3200 to $5000 \mathrm{ml}$ ). Group II patients received $4700 \mathrm{ml}$ placebo drink ( $95 \%$ confidence limits of the median: 4000 to $5350 \mathrm{ml}$ ). Table II shows the median daily quantity and the number of patients who received either Nutridrink or placebo.

The tube was in place and in use median 3.1 days in group I, 3.0 days in group II (NS). The median number of feeding days was five days in both groups including the day of operation. The incidence of nausea, vomiting, and meteorism was not different in the two groups (group I/group II nausea: 19 of 22, vomiting: 15 of 17 , and meteorism: 10 of 16 ).

On the second postoperative day the group I patients passed wind, the group II patients passed wind on the third postoperative day. The patients, who received Nutridrink passed stools after median 2.5 days. The patients, who received placebo passed stools after a median four days (Mann-Whitney test, $p=0 \cdot 010$, two tailed test.

The group I patients were discharged median day 8 after the operation, group II median day 11.5 (two sample rank sum test, $p$ two tailed $=0 \cdot 08$ ).

The mortality was six of 60 patients. In group I two died, one had acute myocardial infarction and one had an anastomotic leak and died after reoperation. In group II four died, one from pulmonary failure, two had an anastomotic leak and died after reoperation, and one died from septicaemia. Eight patients were tranferred to the intensive care unit, two patients in group I (died in the intensive care unit day 3 and day 6), six in group II (three patients were transferred from the intensive care unit after three, 10 and 105 days, three patients died after three, six, and six days in the intensive care unit). 
TABLE III Number of patients with complications

\begin{tabular}{llc}
\hline & $\begin{array}{l}\text { Group I } \\
\text { (Feeding) }\end{array}$ & $\begin{array}{l}\text { Group II } \\
\text { (Placebo) }\end{array}$ \\
\hline Anastomotic leak & 2 (one died) & 4 (two died) \\
Dehiscence & 3 & 0 \\
Acute myocardial infarction & 1 (died) & 0 \\
Pulmonary failure - ARDS & 0 & 1 (died) \\
Wound infection (Buzby II-IV) & 1 & 10 \\
Intra-abdominal abscess/peritonitis & 0 & 2 (one died) \\
Pneumonia & 1 & 2 \\
Total postoperative complications & 8 & $19(\mathrm{p}=0 \cdot 0089)$ \\
Total infectious complications & 2 & $14(\mathrm{p}=0 \cdot 0009)$ \\
\hline
\end{tabular}

Two patients in group I and five patients in group II received total parenteral nutrition (TPN) after they had completed the protocol.

The median cost per patient in group I was estimated to be $43.270 \mathrm{DKK}$ (range 24.076 DKK-189.746 DKK), in group II median cost was 58.385 DKK (range 30.102 DKK$1 \cdot 740.967$ DKK).

A total of 27 patients had complications and of these 16 had infectious complications (Table III).

\section{Discussion}

We found that administration of enteral nutrition after major abdominal surgery is followed by a considerable reduction in postoperative infectious complications compared with placebo.

In the placebo group 14 of 30 patients had infectious complications. Ten of these patients $(33 \%)$ had wound infection, this is comparable to the rates in other studies (Sagar: five of 15 control patients, and Rana: eight of 20 control patients). ${ }^{16}$ Generally the incidence of wound infection is expected to be lower. In this study the high incidence probably results from the control made by the principal investigator until the 30th postoperative day. Only four of 10 wound infections were diagnosed while the patient was still in hospital. Six infections were diagnosed after discharge and would normally have been treated by the patient's general practitioner.

Von Meyenfeldt et al concluded that preoperative nutritional support (TPN or TEN), in patients with severe preoperative depletion, resulted in a reduction in major complications. ${ }^{7}$ This is comparable with the results of The Veterans Affairs Total Parenteral Nutrition Cooperative Study Group but this study also concluded that TPN should be limited to patients who are severely malnourished. ${ }^{8}$ Borderline or mildly malnourished patients had no benefit of perioperative TPN but had more infectious complications than controls. We only had nine malnourished patients in our study but three of five patients in group II had a severe complication and one had a wound infection, none of the patients in group I (four patients) had any complications. This confirms the theory that the malnourished patients will benefit from nutritional support. In our study all nutritional support was given postoperatively. There were no complications resulting from the nutritional supplement.

In 1992 Campos and Meguid reviewed the literature on nutritional support. ${ }^{9}$ They identified 22 prospective studies in English on perioperative nutritional support from 1977 to 1991. Only in two studies did the authors compare postoperative enteral nutritional support with conventional treatment. ${ }^{12}$ These studies were not placebo controlled or blinded.

Our study is the first to be carried out as a placebo controlled trial.

The enteral route is the preferred method for the administration of nutrition. Enteral nutrition can be safely given to patients with a bowel resection from within a few hours of surgery and does not affect how the patients feel in the postoperative period. Also the bowel functions are re-established within a few days and before those patients receiving placebo (no nutrition). Furthermore, the cost of the patient's stay in hospital is reduced by 25 per cent.

Nutricia Research, Zoetermeer, the Netherlands kindly contributed financially to the study. The study was supported by a grant from The Vibeke Binder and Povl Riis Foundation. Thanks to Senior lecturer Jens Kondrup MD Dr Med Sci for valuable discussions and advice.

1 Sagar S, Harland P, Shields R. Early postoperative feeding with elemental diet. $B M F$ 1979; 1: 293-5.

2 Moore E, Jones T. Nutritional assessment and preliminary report on early support of the trauma patient. $\mathcal{f} \mathrm{Am}$ Coll Nutr 1983; 2: 45-54.

3 Moore FA, Feliciano DV, Andrassy RJ, McArdle AH, Mcl Booth FV, Morgenstein-Wagner TB, et al. Early enteral feeding, compared with parenteral reduces postoperative septic complications. Ann Surg 1992; 216: 172-83.

4 Everitt N, McMahon M. Nutrition and the surgical patient. In: Heatley RV, Green JH, Losowsky MS eds. Consensus in clinical nutrition. Cambridge: Cambridge University Press, 1994: 239-55.

5 Buzby GP, Knox LS, Crosby LO, Eisenberg JM, Haakenson CM, McNeal GE, et al. Study protocol: a randomized clinical trial of total parenteral nutrition in malnourished surgical patients. Am $₹$ Clin Nutr 1988; 47: 366-81.

6 Rana SK, Bray J, Menzies-Gow N, Jameson J, Payne James J, Frost P, et al. Short term benefits of postoperative oral dietary supplements in surgical patients. Clin Nutr 1992; 11: 337-44.

7 Von Meyenfeldt MF, Meijerink WJHJ, Rouflart MMJ, Builmaassen MTHJ, Soeters PB. Perioperative nutritional support: a randomised clinical trial. Clin Nutr 1992; 11: 180-6.

8 The Veterans Affairs Total Parenteral Nutrition Cooperative Study Group. Perioperative total parenteral nutrition in surgical patients. $N$ Engl $\mathcal{Y}$ Med 1991 ; 325: 527-32.

9 Campos ACL, Meguid MM. A critical appraisal of the usefulness of perioperative nutritional support. Am $\mathcal{F}$ Nutr 1992; 55: $117-30$. 